\title{
Three new species of Begonia (Begoniaceae) from Sumbawa Island, Indonesia
}

\author{
D. Girmansyah \\ Herbarium Bogoriense, Research Center for Biology, \\ Indonesian Institute of Sciences, JI. Raya Jakarta-Bogor Km 46, \\ Cibinong, 16911, Bogor, West Java, Indonesia \\ deden_bo@yahoo.com
}

ABSTRACT. Three new species of Begonia L., Begonia sumbawaensis Girm., Begonia brangbosangensis Girm. and Begonia jaranpusangensis Girm., are described from Sumbawa, Indonesia. All species are illustrated and identification keys and distribution maps are provided.

Keywords. Begonia sect. Petermannia, Begonia sect. Reichenheimia, Betunin, endemic

\section{Introduction}

Begonia L. (Linnaeus, 1753), is currently estimated to have around 1803 species distributed throughout tropical and subtropical Asia, Africa and America (Hughes et al., 2015b). In Southeast Asia, Indonesia is a centre of diversity for Begonia and many new species are still being discovered (Girmansyah \& Susanti, 2015; Hughes et al., 2015a; Undaharta et al., 2015). Currently, 231 accepted species of Begonia are known from Indonesia, distributed from Sumatra to Papua. In Sumbawa (West Nusa Tenggara), only three species have been recorded to date (Begonia bimaensis Undaharta \& Ardaka (Undaharta et al., 2015), B. multangula Blume (Hughes et al., 2015 b) and B. muricata Blume (Hughes, 2008). Some specimens previously attributed to Begonia muricata are included below in the new species B. sumbawaensis.

Sumbawa is situated between Lombok to the west and Flores to the east. Botanical exploratory efforts on Sumbawa are summarised in Van Steenis-Kruseman (1950). Recent botanical explorations in March 2004 and July 2005 conducted by Herbarium Bogoriense (RCB-LIPI) and sponsored by the New England Tropical Conservatory, USA resulted in three new species of Begonia being collected. The new species were collected from the Mt Batu Pasak complex, the Mt Ngengas complex and the Jaran Pusang complex (Fig.1).

Three new species, Begonia sumbawaensis Girm., Begonia brangbosangensis Girm. and Begonia jaranpusangensis Girm., are described here. Begonia sumbawaensis is placed in Begonia sect. Reichenheimia (Klotzsch) A.DC. (De Candolle, 1859) as it exhibits the characters typical of the section: rhizomatous stems, protandrous inflorescences, and three locular ovaries with entire placentae (Doorenbos et al., 1998). Begonia jaranpusangensis and B. brangbosangensis are placed in Begonia sect. Petermannia (Klotzsch) A.DC. (De Candolle, 1859) as they exhibit characters 


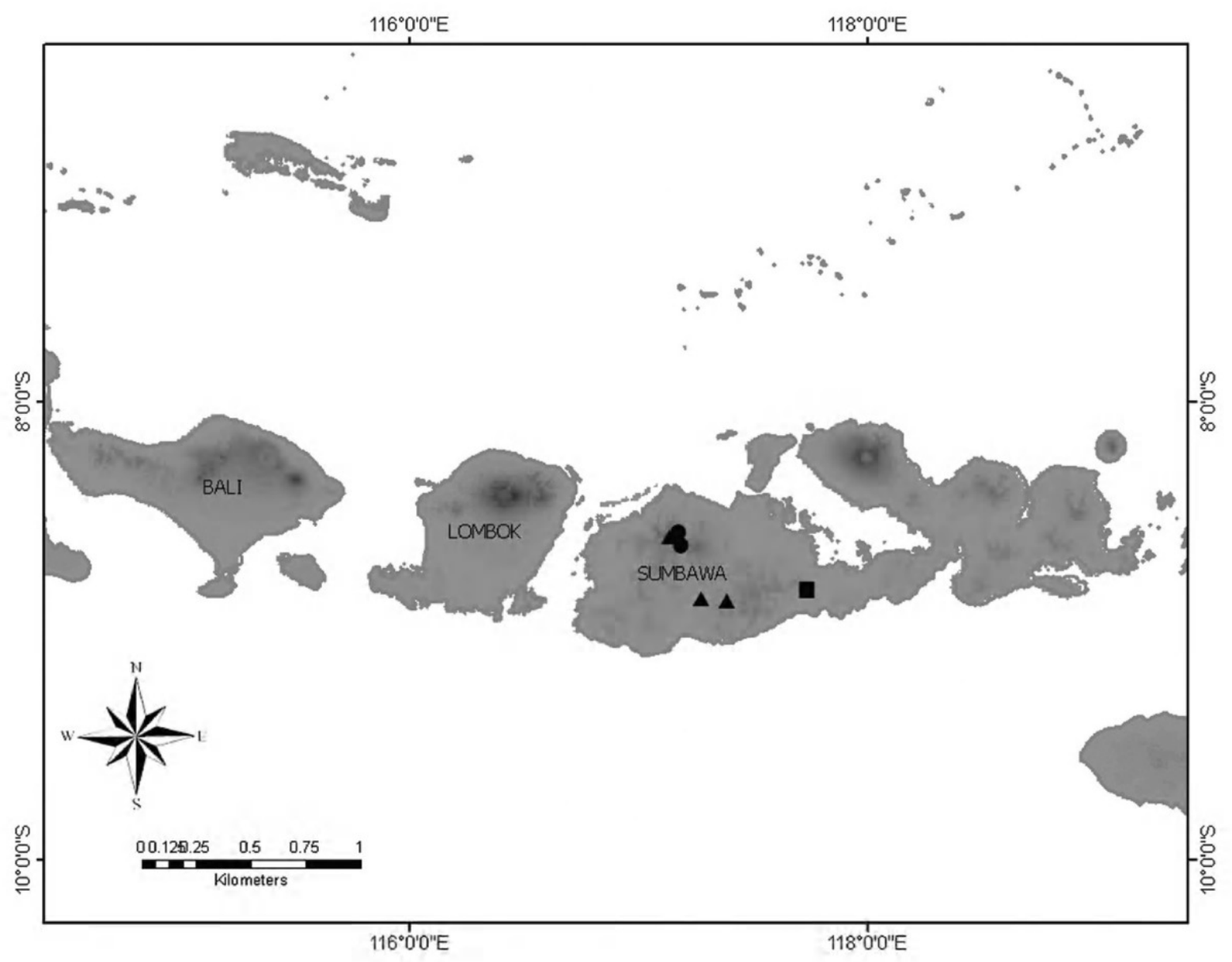

Fig 1. Distribution of Begonia sumbawaensis Girm. (triangles), B. brangbosangensis Girm. (circles) and B. jaranpusangensis Girm. (square).

typical of the section: upright stems, protogynous inflorescences, and three locular ovaries with branched placentas (Doorenbos et al., 1998).

Key to the species of Begonia from Sumbawa

1a. Rhizomatous or tuberous herb; leaves ovate to broadly ovate 2

1b. Erect herb; leaves ovate to oblong 3

2a. Base tuberous; leaves lobed, upper surface with long hairs B. bimaensis

2b. Base rhizomatous; leaves entire, upper surface glabrescent B. sumbawaensis

3a. Leaves broadly ovate or orbicular, margin shallowly lobed; fruit fleshy and indehiscent

B. multangula

3b. Leaves elliptic, oblong, ovate or narrowly ovate, margin entire; fruit dry and dehiscent 
4a. Leaves ovate to elliptic; petiole hairy

B. jaranpusangensis

4b. Leaves narrowly ovate to oblong; petiole glabrous

B. brangbosangensis

Begonia sumbawaensis Girm., sp. nov. $§$ Reichenheimia

Similar to Begonia lugrae Ardhaka \& Undaharta (Ardi et al., 2013) but differs in having tomentose petioles (not glabrous), stipule narrowly triangular (semicircular in Begonia lugrae), female flower tepals four (three in Begonia lugrae) and stamens 48 (90 in Begonia lugrae). - TYPE: Indonesia, West Nusa Tenggara, West Sumbawa, Betunin Hill, 10 July 2005, Deden Girmansyah 461 (holotype BO; isotypes BO, E). (Fig. 2)

Perennial, creeping, rhizomatous monoecious herb, up to $30 \mathrm{~cm}$ tall. Stems rhizomatous, rooting at the nodes, internodes very close, 5-10 $\mathrm{mm}$ long; stipules narrowly triangular, with dense hairs along the dorsal vein, $9 \times 4.5 \mathrm{~mm}$, with a hairlike appendage at the apex covered with additional dense hairs, semi persistent. Leaves alternate; petioles 10-25 cm long, tomentose, reddish; lamina basifixed, 10-30 $\times 9-29$ $\mathrm{cm}$ (in live material), asymmetric, suborbicular to broadly ovate, base cordate, lobes overlapping, apex acute to attenuate, margin sub-entire, with minute teeth at the end of the veins, adaxial surface glabrescent to sparsely hairy, light green; abaxial surface shiny red with scattered short hairs, venation palmate, primary veins 7-8. Inflorescence cymose, with 6-10 flowers, axillary, protandrous, bisexual; peduncle 10-30 cm long, diameter 2-4 mm, puberulous; bracts sub-orbicular, red, c. $3.3 \times 2.5$ $\mathrm{mm}$, margin slightly fimbriate, persistent. Male flowers: pedicels c. $2 \mathrm{~cm}$ long, hairy; tepals 4, white to reddish, two outer tepals sub-orbicular, $1.4-2 \times 1.2-1.5 \mathrm{~cm}$, base slightly cordate, margin entire, apex rounded or slightly undulate, glabrous; two inner tepals narrowly obovate, white, $1.2-1.5 \times 0.8-1 \mathrm{~cm}$, glabrous; androecium symmetric, the cluster globose; stamens yellow, c. 48 in number, subequal; filaments 1-1.5 mm long, fused at the base; anther obovoid, c. $1 \mathrm{~mm}$ long, dehiscing through unilateral slits as long as anther. Female flowers: pedicels $12-18 \mathrm{~mm}$ long, puberoulus; tepals 4, unequal, two outer tepals orbicular to broadly ovate, c. $11 \times 14 \mathrm{~mm}$, margin entire, apex rounded, two inner tepals narrowly obovate, c. $10 \times 5 \mathrm{~mm}$; ovary sub-globose, 5-7 $\times 2-3 \mathrm{~mm}$, locules 3 , placentation axile, entire, wings 3 , unequal, obtuse at the apex, the widest point at the middle of the ovary, $5 \mathrm{~mm}$ wide, glabrous; stigmas 3 , yellowish green, Y-shaped, $3 \mathrm{~mm}$ long. Fruits with pedicels $2.2-3 \mathrm{~cm}$ long; capsule ellipsoid, 6-10 $\times$ 4-8 mm (excluding wings), dehiscent, splitting between the locules and wings, wings 3 , subequal, wings $7-10 \mathrm{~mm}$ at the widest point, thinly fibrous. Seeds barrel-shaped, $0.35-0.37 \mathrm{~mm}$ long, collar cells more than a half of seed length.

Distribution. Endemic to West Sumbawa, West Nusa Tenggara, Indonesia.

Habitat. Terrestrial herb on steep slopes in tropical forest between 1300-1600 m alt.

Additional specimens examined. West Nusa Tenggara: West Sumbawa, Batu Linting, 15 Jul 2005, Deden Girmansyah 506 (BO); West Sumbawa, Mt Batu Pasak, 18 July 2005, Deden 


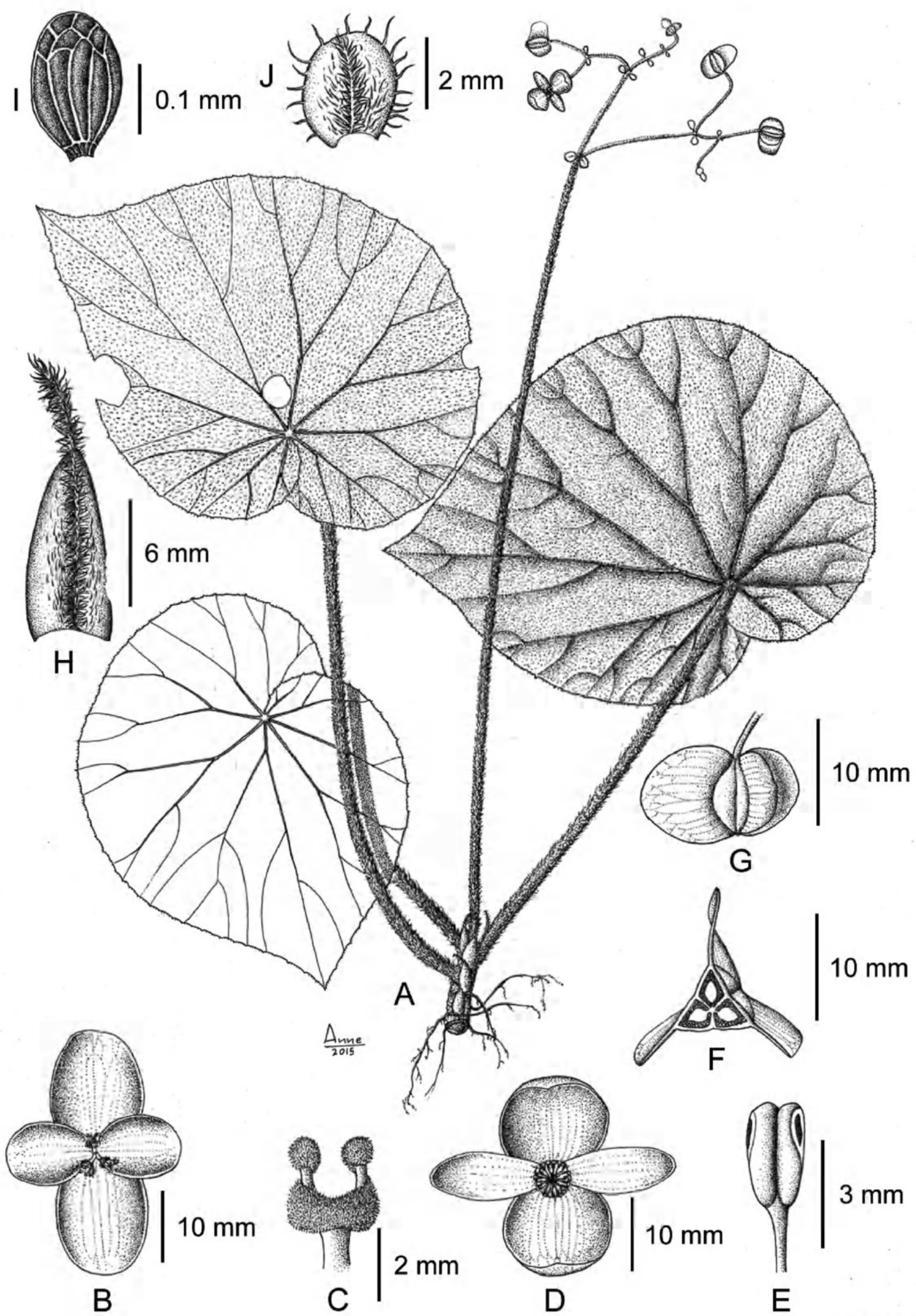

Fig. 2. Begonia sumbawaensis Girm. A. Habit. B. Female flower. C. Style. D. Male flower. E. Stamen. F. Fruit in cross section. G. Fruit. H. Stipule. I. Seed. J. Bract. Drawn by A. Kusumawati. 
Girmansyah 535 (BO); West Sumbawa, Olat Tebelah Hill, 9 Jul 2005, Deden Girmansyah 429 (BO); West Sumbawa, Upper Batu Dulang, Brang Bosang River Slope of Batu Linting, 15 Jul 2005, HW 12644 (BO); ZW Sumbawa, De Voogd 1634 (BO); West Sumbawa, Mt Batulanteh, 22 Apr 1961, Kostermans 18400 (A, K); West Sumbawa, September 1879, Colfs 299 (L [3 sheets]).

Notes. The epithet is derived from the name of Sumbawa Island, With its creeping habit Begonia sumbawaensis is typical for Begonia sect. Reichenheimia. It is a very attractive species with bright red petioles and leaf undersides, and with the inflorescence being longer than the petioles and bearing many flowers. As such the plant has potential for ornamental use. This species is found on steep slopes and hence was very difficult to collect.

\section{Begonia brangbosangensis Girm., sp. nov. §Petermannia}

Begonia brangbosangensis differs from B. lombokensis Girm. (Girmansyah, 2009) in having the female flower solitary in the leaf axils (in pairs in B. lombokensis), number of stamens 45 (24 in B. lombokensis), and the female flower pedicel $0.5-0.8$ $\mathrm{cm}$ long (1.3 cm long in B. lombokensis). - TYPE: Indonesia, West Nusa Tenggara, West Sumbawa, Brang Bosang river, upper Batu Dulang Village, 18 July 2005, Deden Girmansyah 528 (holotype BO; isotypes BO, E). (Fig. 3)

Perenial, erect, monoecious herb, $1 \mathrm{~m}$ tall. Stems erect, internodes $2-10 \mathrm{~cm}$ long, diameter 5-7 mm; stipules narrowly lanceolate, c. $10 \times 4.5 \mathrm{~mm}$, pale green, glabrous, persistent. Leaves alternate; petioles $2-5 \mathrm{~cm}$ long, glabrous, green or reddish; lamina narrowly ovate to oblong, basifixed, asymmetric, 9-20 $\times 2.5-6 \mathrm{~cm}$, base subcordate, margin distantly serrulate, apex attenuate, adaxial surface green, glabrous, abaxial suface green; venation pinnate, primary veins 3-4 pairs along the midrib; impressed above, prominent beneath, pale green to burgundy beneath, glabrous. Inflorescence racemose, bisexual, 3-7 cm long, erect, male flowers distal, female flowers basal; peduncle 1-3 cm; bracts bright green, elliptic, $9 \times 3 \mathrm{~mm}$, margin entire, caducous. Male flowers: pedicels c. $1 \mathrm{~cm}$ long, glabrous; tepals 2, white to pink, broadly elliptic, 8-10 × 6-9 mm, margin entire, glabrous; androecium c. $0.4 \mathrm{~mm}$ long, stamens c. 45 in number, filaments $1-1.5 \mathrm{~mm}$ long, fused at the base, anther pale yellow c. $1 \mathrm{~mm}$ long, obovoid, dehiscing through unilateral slits c. $1 / 3$ as long as anther. Female flowers: pedicels 5-10 mm long, green, glabrous; tepals 2, white, obovate, base subcordate, apex obtuse to rounded, equal, glabrous, c. $12 \times 10 \mathrm{~mm}$; ovary pale green to reddish brown, subglobose to ovoid, 8-15 $\times 8-13 \mathrm{~mm}$ (wings included), capsule ovoid, locules 3 , placentation axillary, placental branches 2 per locule; wings 3 , unequal, rounded at the apex, 3-5 mm wide; styles 3, yellow, c. $6 \mathrm{~mm}$ long, free to the base, bifurcating with pale yellow stigma. Fruits with pedicel $15 \mathrm{~mm}$ long, capsule ellipsoid, 8-20 $\times 5-9 \mathrm{~mm}$ (excluding wings), dehiscent, splitting between the locules and wings, glabrous, wing shape as for ovary, wings $8-10 \mathrm{~mm}$ wide at the widest point. Seeds numerous, brown, ellipsoid, $0.34-0.36 \mathrm{~mm}$ long, collar cells more than a half of seed length. 


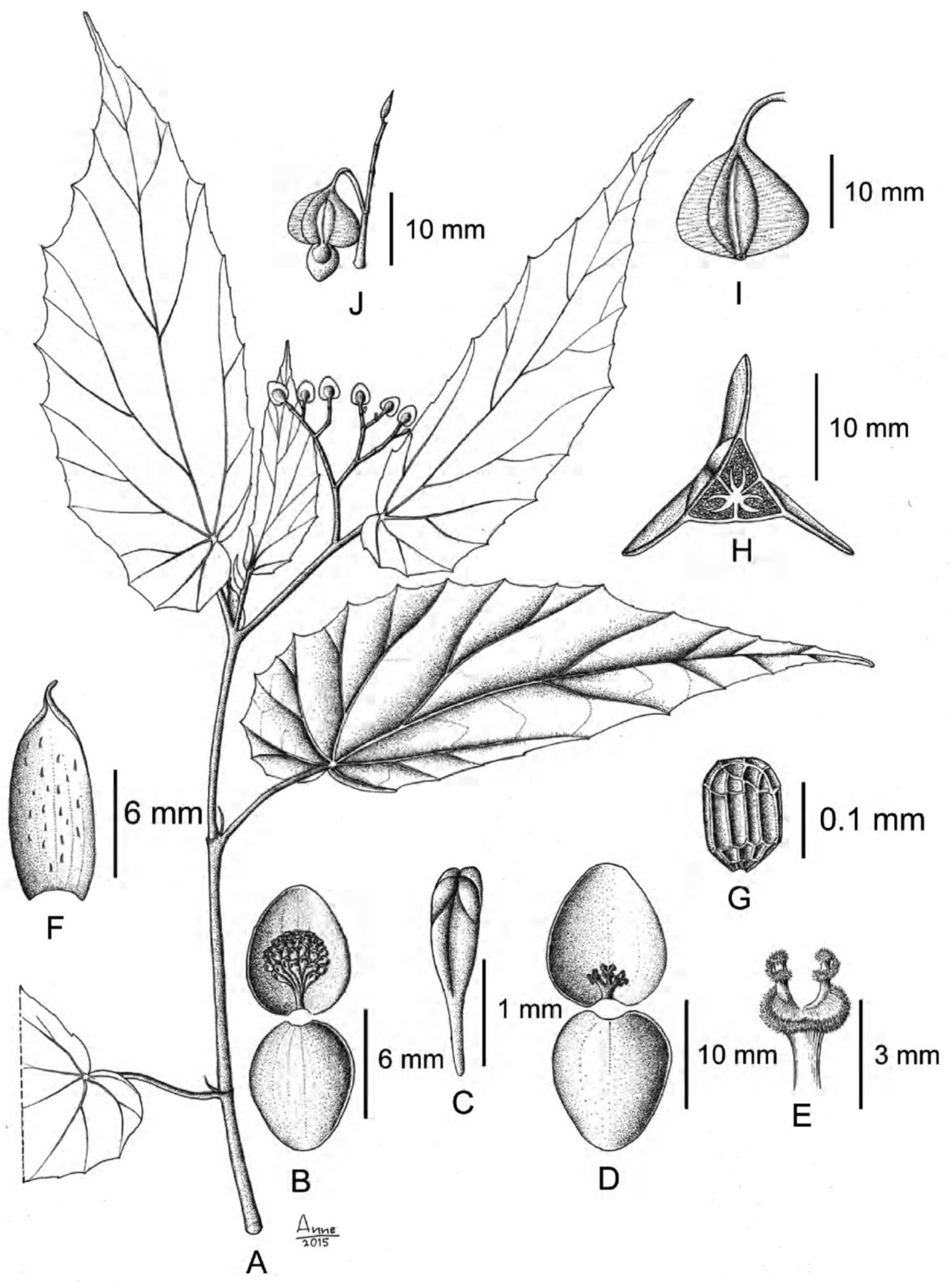

Fig. 3. Begonia brangbosangensis Girm. A. Habit. B. Male flower. C. Stamen. D. Female flower. E. Style. F. Stipule. G. Seed. H. Fruit in cross section. I. Fruit. J. Ovary. Drawn by A. Kusumawati. 
Distribution. Endemic to West Sumbawa, Sumbawa, West Nusa Tenggara, Indonesia.

Habitat. Terrestrial on the forest floor on wet and moist substrates especially along stream margins and river banks at 1300-1700 m altitude.

Additional specimens examined. West Nusa Tenggara: West Sumbawa, between Brangbosang river and Mt Batulinting, 15 Jul 2005, Deden Girmansyah 509 (BO); West Sumbawa, Upper Tepal Traditional Village, slope of Mt Ngengas, top of Batu Tunin, East Mountain Forest, 10 Jul 2005, Deden Girmansyah 463 (BO); West Sumbawa, upper Tepal Traditional village, Olah Tebelat, Pagenong, slope of Mt Ngengas, 9 Jul 2005, Deden Girmansyah 432 (BO); West Sumbawa, Mt Batulanteh, trail from Batu Dulang to Pusu, 19 Apr 1961, Kostermans 18347 (A, BO,K); West Sumbawa, Mt Batulanteh, 22 Apr 1961, Kostermans 18396 (A, BO, K).

Notes. The epithet is derived from the name of the Brang Bosang River in West Sumbawa.

\section{Begonia jaranpusangensis Girm., sp. nov. § Petermannia}

Begonia jaranpusangensis is similar to B.padangensis Irmsch. in habit and in having hairy petioles, but differs in having two tepals in the male flowers (four in $B$. padangensis), two tepals in the female flowers (five in B. padangensis), and female flower pedicels $0.5-0.7 \mathrm{~cm}(10-15 \mathrm{~mm}$ in $B$. padangensis $)$ - TYPE: Indonesia, West Nusa Tenggara, West Sumbawa, Plampang, between Tana Sílo to slope of Mt JaranPusang, 23 July 2005, Deden Girmansyah 552 (holotype BO; isotypes BO, E). (Fig. 4)

Perenial, erect, monoecious herb, $1 \mathrm{~m}$ tall. Stem green to reddish green, hirsute, 3-10 $\mathrm{mm}$ diameter when fresh, internodes $2-10 \mathrm{~cm}$ long; stipules narrowly lanceolate, green, puberulent, 15-25 $\times 4-8 \mathrm{~mm}$, margin entire, apex acuminate, ending with a short hair, 1-2 mm long, persistent. Leaves alternate; distant; petioles red, pilose, 1-5 cm long, diameter 2-3 mm, grooved above; lamina basifixed, ovate to elliptic, 11-18 $\times 5-9 \mathrm{~cm}$, asymmetric, base rounded on the broad side and cuneate on the narrow side, broad side 4-6.5 cm wide, narrow side 1-3 cm wide, margin denticulate, apex acute to attenuate; venation pinnate, primary veins 5-6 pairs, impressed above, prominent beneath. Inflorescences racemose, protogynous, bisexual; male inflorescence monochasial at base, sympodial at apex, peduncle $1.5-2.5 \mathrm{~cm}$ long, erect, paniculate; female inflorescence a simple dichasium with a pair of flowers, peduncle $2.5-3 \mathrm{~cm}$ long; bracts bright green, narrowly elliptic, c. $15 \times 5 \mathrm{~mm}$, persistent. Male flowers: pedicels $2-2.5 \mathrm{~cm}$ long, white to pinkish, glabrous; tepals 2 , suborbicular to broadly ovate , white to pink, $12 \times 9-10 \mathrm{~mm}$, margin entire, apex rounded, glabrous; androecium c. 5 $\mathrm{mm}$ long, stamens c. 34 in number, filaments $1-1.5 \mathrm{~mm}$ long, fused at the base, anthers pale yellow 1.5-2 mm long, obovoid, dehiscing through unilateral slits c. $1 / 2$ as long as anther. Female flowers: pedicels green, puberulent, 5-8 mm long; tepals 5, white, narrowly elliptic to lanceolate, glabrous, $12-13 \times 6-8 \mathrm{~mm}$; ovary pale green, triangular in outline, $10 \times 4 \mathrm{~mm}$ (wings included), wings 3 , subequal, rounded at the apex, the 


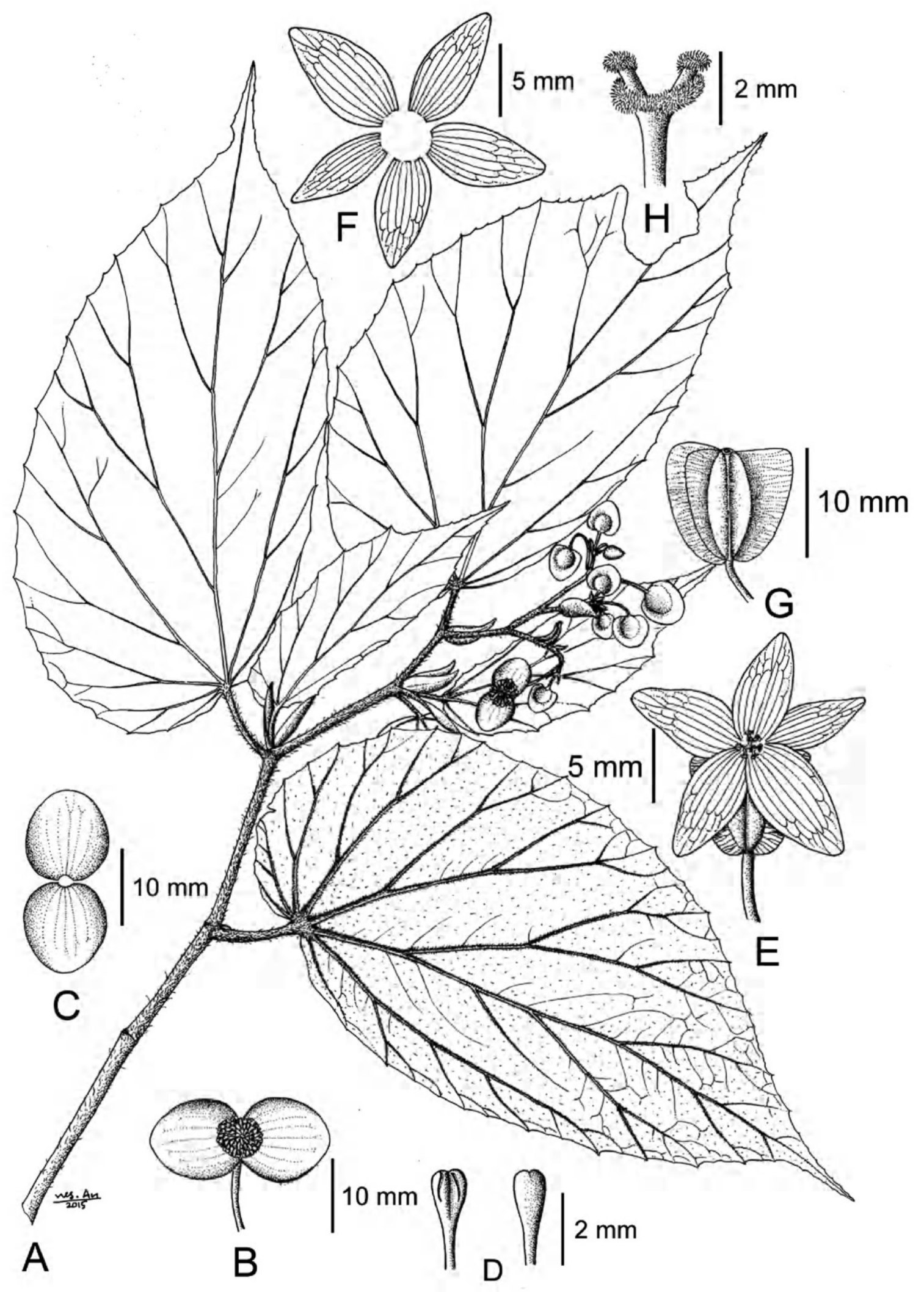

Fig. 4. Begonia jaranpusangensis Girm. A. Habit. B. Male flower. C. Male flower tepal. D. Stamen. E. Female flower. F. Female flower tepal. G. Fruit. H. Style. Drawn by A. Kusumawati \& Wahyudi. 
widest point $5 \mathrm{~mm}$ wide; styles 3, yellow, 4-5 mm long. Fruits with pedicel c. $15 \mathrm{~mm}$, capsule c. $2 \times 1.5 \mathrm{~cm}$ (excluding wings), dehiscent, splitting between the locules and wings. Seeds numerous, brown, broadly ellipsoid to ellipsoid, c. $0.31-0.35 \mathrm{~mm}$ long.

Distribution. Endemic to Mt Jaranpusang, West Sumbawa district, Sumbawa, West Nusa Tenggara, Indonesia.

Habitat. Terrestrial herb, found on the slope of Mt Jaranpusang in rather dry conditions, at c. $615 \mathrm{~m}$ altitude.

Additional specimens examined. West Nusa Tenggara, West Sumbawa, Plampang, between Tana Silo to slope of Mt Jaranpusang, 23 Jul 2005, Deden Girmansyah 461 (BO).

Notes. The species epithet is derived from the name of Mt Jaran Pusang in West Sumbawa. Mount Jaran Pusang is separate from the mountains in the central Mt Pasak complex and has a drier climate. The base of the mountain is covered by bamboo gardens and the habitat is noticeably dry in appearance. The peak of Mt Jaran Pusang is rocky and there are few trees of any size; the floristic composition is also rather different compared with the flora from elsewhere in the middle of West Sumbawa. Begonia jaranpusangensis was collected from the middle slopes of Mt Jaran Pusang and is only known from this site.

ACKNOWLEDGEMENTS. I am grateful to the Director of Herbarium Bogoriense for making available the specimens to study, Dr Harry Wiriadinata and Mr Scott Hoover who encouraged me to collect Begonia specimens during their 2004 and 2005 expeditions to West Sumbawa sponsored by the New England Tropical Conservatory (NETC), and Dr Mark Hughes from the Royal Botanic Garden Edinburgh for comments on an earlier version of the manuscript and for his assistance with the English. I would like to thank Wahyudi Santoso and Anne Kusumawati for their excellent line drawings.

\section{References}

Ardi, W.H., Ardhaka, I.M., Hughes, M., Undaharta, N.K.E., Girmansyah, D. \& Hidayat, S. (2013). Two new species of Begonia (Begoniaceae) from Bali and Lombok. Gard. Bull. Singapore 65(2): 135-142.

De Candolle, A.L.P.P. (1859). Mémoire sur la famille des Bégoniacées. Ann. des Sci. Nat., Bot. 11: 93-149.

Doorenbos, J., Sosef, M.S.M. \& De Wilde, J.J.F.E. (1998). The sections of Begonia including descriptions, keys and species lists (Studies in Begoniaceae VI). Wageningen Agric. Univ. Pap. 98: 1-266.

Girmansyah, D. (2009). A taxonomic study of Bali and Lombok Begonia (Begoniaceae). Reinwardtia 12(5): 419-434.

Girmansyah, D. \& Susanti, R. (2015). Two new species of Begonia (Begoniaceae) from Borneo. Kew Bull. 70(2)-19: 1-7. 
Hughes, M. (2008). An Annotated Checklist of Southeast Asian Begonia. xii +164 p. UK: Royal Botanic Garden Edinburgh.

Hughes, M., Girmansyah, D. \& Ardi, W. (2015a). Further discoveries in the ever-expanding genus Begonia (Begoniaceae): Fifteen new species from Sumatra. Eur. J. Taxon. 167: 1-40 http://m.europeanjournaloftaxonomy.eu/index.php/ejt/article/view/289 (accessed on 28 Dec. 2015).

Hughes, M., Moonlight, P., Jara, A. \& Pullan, M. (2015b). Begonia Resource Centre. Royal Botanic Garden Edinburgh http://elmer.rbge.org.uk/begonia/ (accessed on 22 Dec. 2015).

Linnaeus, C. (1753). Species plantarum: exhibentes plantas rite cognitas, ad genera relatas, cum differentiis specificis, nominibus trivialibus, synonymis selectis, locis natalibus, secundum systema sexuale digestas. Holmiae: Laurentii Salvii.

Undaharta, N.K.E., I Made Ardaka, Agung Kurniawan \& Bayu Adjie (2015). Begonia bimaensis, a new species of Begonia from Sumbawa Island, Indonesia. Gard. Bull. Singapore 67(1): 95-99.

Van Steenis-Kruseman, M.J. (1950). Malaysian plant collectors and collections: Being a cyclopedia of botanical exploration in Malaysia and a guide to concerned literature up to the year 1950. Flora Malesiana, Ser. I, 1: 5-605. Jakarta: P. Noordhoff. 


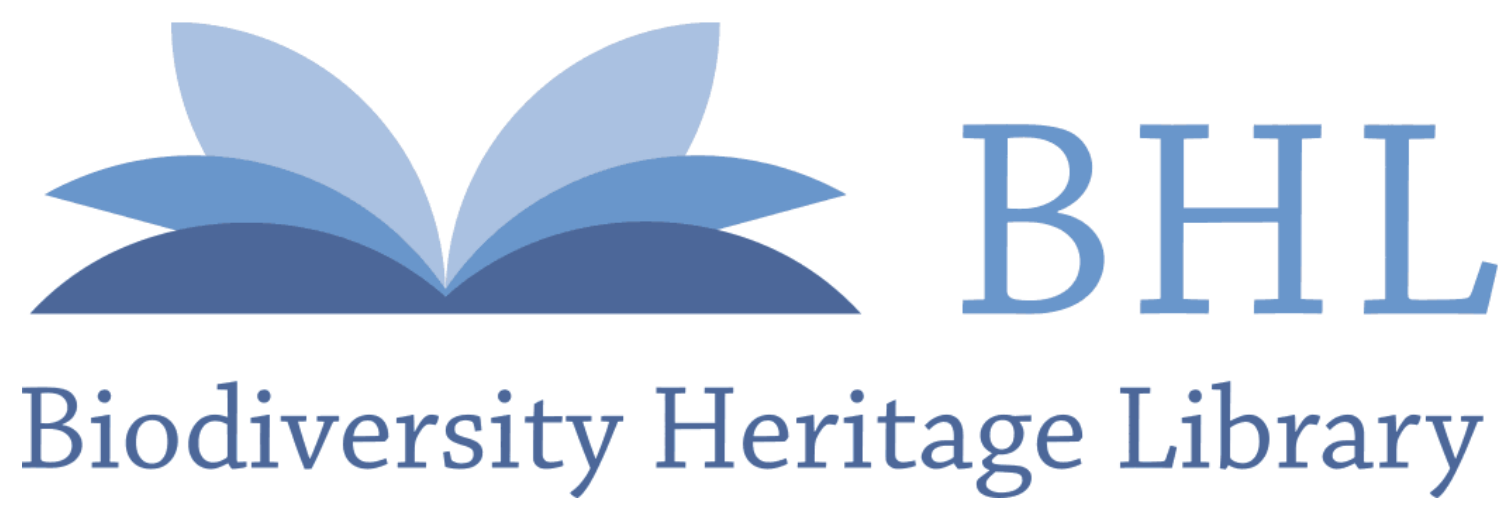

Girmansyah, Deden. 2016. "Three new species of Begonia (Begoniaceae) from Sumbawa Island, Indonesia." The Gardens' bulletin, Singapore 68(1), 77-86. https://doi.org/10.3850/s2382581216000041.

View This Item Online: https://www.biodiversitylibrary.org/item/223155

DOI: https://doi.org/10.3850/s2382581216000041

Permalink: https://www.biodiversitylibrary.org/partpdf/229537

\section{Holding Institution}

Singapore Botanic Gardens, National Parks Board Singapore

\section{Copyright \& Reuse}

Copyright Status: In copyright. Digitized with the permission of the rights holder.

License: http://creativecommons.org/licenses/by-nc-sa/4.0/

Rights: https://biodiversitylibrary.org/permissions

This document was created from content at the Biodiversity Heritage Library, the world's largest open access digital library for biodiversity literature and archives. Visit BHL at https://www.biodiversitylibrary.org. 